\title{
IMPLEMENTATION OF INTEGRATED CUSTOMS RISK MANAGEMENT IN UKRAINE
}

The article is devoted to the peculiarities of implementation of integrated customs risk management in Ukraine. The authors analyze the basic principles and requirements of international standards for the customs risk management. The stages of customs risk management formation in Ukraine and prospects of its development are determined. Attention is paid to the implementation of international enforcement information systems to ensure compliance with the legislation throughout the supply chain. The role of forming the maturity of risk management is emphasized for the implementation of integrated risk management in the customs authorities. The ways of implementation of integrated customs risk management are offered and an innovative model of integrated risk-management in the activity of customs bodies of Ukraine is developed on base the quality management, change management and knowledge management. The use of different types of benchmarking in the implementation of the proposed model is seen as an effective tool for improving the efficiency of all activities and management of the customs system.

Key words: international standards, integrated risk management, customs risks, automated risk analysis and management system, innovative model, quality management, change management, knowledge management.

JEL Classification: F130, F590.

\section{Halyna RAZUMEI,}

Senior Lecturer at the Department of Public Governance and Customs Administration

University of Customs and Finance $P h D$ in Public Administration galchata86@gmail.com

\section{Maksym RAZUMEI} Head of Risk Management Department, Dnipropetrovsk's Customs of SFS, PhD in Public Administration m.razumey@gmail.com

\section{Introduction.}

Customs administrations operate in a complex environment of constant change. They are required to respond to the promotion of economic development and to comply with regional, national and international obligations. Like any organization Customs faces internal and external uncertainties that affect its ability to achieve its goals. According to the international standard ISO 31000 (2018) «Risk management - Principles and guidelines on implementation» the effect of uncertainty on an organization's objectives is risk. All directions of activity in every organization involve risks, and the State Fiscal Service of Ukraine (hereinafter - SFS) is no exception. Thus, efficient management of customs risks is one of the most strategic tasks of the SFS.

Risk Management was recognized by all customs administrations as a new philosophy of customs control, which helps to be a maximum effectively used resource at the border for fast goods movement, transport and passengers with the providing safety of the society within it. 
So implementation of risk management in customs context should based on an experience of private and public sector in developed countries.

The aim of this paper is to analyze the features of implementation the risk management methodology in the customs affairs of Ukraine, taking into account international standards and requirements of the EU legislation, and to develop the proposals for the implementation of the integrated customs risk management model based on quality, knowledge and change management for both compliance and trade facilitation.

Literature Review

The main basis for customs risk management researches is the international agreements, conventions and other legislations in the international trade and customs affairs, the international standards and methodological papers in this field and also case study of different countries to choose the best experience.

The issue of implementation of customs international standards in national legislation and specific mechanisms for its implementation were studied in the works of domestic and foreign customs theorists and practitioners. Some aspects of customs regulation of foreign trade activity in Ukraine and the role of customs in ensuring national security were studied by Berezhnyuk (2009), Borysenko (2012), Chentsov (2012), Czyżowicz (2015), Ivashova (2008), Kveliashvili (2010), Mashiri \& Sebele-Mpofu (2016) and others.

Following the renewal of the Kyoto Convention (1999), after the adoption of SAFE Framework of Standards to Secure and Facilitate Global Trade (WCO, 2007) and the introduction of risk management systems in the practice of customs formalities around the world, a separate direction of research was devoted to this topic.

One of the first significant research works in this field was written by Widdowson (2003).

In Ukraine Pashko (2009) formed the customs security concept, the main category of which is customs risk. The papers of Tereshchenko (2012), Berezhnyuk (2014), Gellert (2014), Komarov (2016) and others were devoted to problems of organization and improvement customs risk management in Ukraine, institutional and legal aspects of its implementation and mechanism of automation, analysis of foreign experience in this field. Despite the importance of these studies, they emphasized only on the separated parts of risk management system, leaving without consideration the integrated approach to its implement. Therefore, all this resulted in the choice of theme of this paper.

Methodology

To achieve the object of the research, we used the integrated application of general scientific and special methods, in particular: methods of analysis and synthesis - for considering normative and theoretical sources regarding the risk management application in the customs authorities activity; comparative analysis - to study foreign experience of implementing customs risk management and a systematic approach - during the analysis of risk management as a system in the customs authorities of Ukraine. Structural-functional analysis and abstract-logical methods determined the factors of customs risks. Using the method of modeling we developed the innovative model of integrated risk management in the activity of customs authorities of Ukraine.

\section{Results and Discussion}

The functional role of Customs includes the demands of the international community to the customs administrations in the twenty first century and the conventional mission of Customs: «to develop and implement an integrated set of policies and procedures that ensure increased 
safety and security, as well as effective trade facilitation and revenue collection» (World customs organization (hereinafter - WCO), 2008, p. 5).

The most powerful techniques used by Customs agencies to deliver their mission are risk management and audits proclaimed the main methods of customs control in the International Convention on the Simplification and Harmonization of Customs Procedures (hereinafter Kyoto Convention) (WCO, 1999). These techniques allow Customs agencies to assist the vast majority of economic operators who wish to be compliant, and enables them to concentrate their resources on controlling the smaller number who represent the greatest risk to a country. As recognized Jeacocke and Kouwenhoven (2017, p.28), data analytics - for example, automated selectivity rules - has become increasingly important in enabling these techniques.

According to chapter 6 «Customs control» of Kyoto Convention (1999) risk is defined as the potential for non-compliance with Customs laws. So all customs administration must use risk management system in their customs formalities. However, Widdowson (2003) noted that risks to the achievement of organizational goals not only include the potential for non-compliance with customs laws, but also the potential failure to facilitate trade, which is revealed in the process of customs service delivery to trading community.

This statement was confirmed in the SAFE Framework of Standards to Secure and Facilitate Global Trade (WCO, 2007) which provides a model for administrations and governments wishing to develop security measures to facilitate and secure global supply chains. The SAFE Framework bases on four core elements, two of which are directly related to the risk management system:

1. the harmonization of advance electronic cargo information on inbound, outbound and transit shipments;

2. the requirement that each country that joins SAFE commits to employing a consistent risk management approach to address security threats;

3. the requirement that on request of the customs administration in the receiving nation, the customs administration of the sending nation performs an outbound inspection of high-risk containers and cargo using non-intrusive detection equipment;

4. the benefits that Customs authorities will provide to businesses that meet minimal supply chain security standards and best practices, including enhanced trade facilitation for legitimate trade and AEO concept.

The SAFE Framework, based on this core principles, rests on tree pillars 'Customs to Customs', 'Customs to Business', 'Customs to other government and inter-government', each of which involves a set of standards that are consolidated to guarantee ease of understanding and rapid international implementation.

The Risk Management Systems is a key element of the pillar 1 of the SAFE Framework that should include a mechanism for validating threat assessments and targeting decisions and implementing best practices. According to the SAFE Framework (WCO, 2007, p. 13) the Customs administration should establish a risk-management system to identify potentially highrisk cargo and/or transport conveyances and automate that system.

Adherence to the principle of risk-oriented management by the borders much depends on effectiveness of intercommunication between customs administrations, with business communities and other state and intergovernmental agencies, namely realization of the three backbones of Framework security standards and trade facilitation.

The WCO develops more detailed implementing provisions for the risk management: the Risk Management Guide (WCO, 2003); the Global Information and Intelligence Strategy, the 
Standard risk assessment methods, A general indicator of high risk (WCO, 2005) and the Risk Management Compendium (WCO, 2011).

The Compendium is comprised of two separate but interlinked volumes. Volume 1 sets out the organizational framework for risk management and outlines the risk management process. Volume 2 deals with risk assessment, profiling and targeting tools that inform selection criteria for identifying high-risk consignments, passengers and conveyances for Customs intervention.

After taking the WCO Risk Management Compendium in 2011 the customs administrations over the world should implement the principles of international standard of integrated risk management ISO 31000 in their own risk management system. That methodology must allow them to achieve the balance between trade facilitation and regulatory control.

Continuing development of main modern principles of customs affairs, the WCO has dedicated last years of customs administration development with annually slogans 'Digital Customs: Progressive Engagement' (2016), 'Data Analysis for Effective Border Management' (2017) and 'SMART borders for seamless Trade, Travel and Transport' (2019). That statements are noted to the implement both information and communications technologies and innovation in customs control procedures, digital solutions and services. Dr Kunio Mikuriya (2017), Secretary General of the WCO, stated that data analysis plays the critical role in modernizing customs administrations to improve border management. During this process, a proper feedback mechanism will be essential so as to enhance the efficiency of risk management engines.

The World Trade Organization (hereinafter - WTO) Trade Facilitation Agreement (hereinafter -TFA) sets out the obligations relating to risk management in Article 7, sub-paragraph 4, which provides that each WTO member shall:

1. to the extent possible, adopt or maintain a risk management system for customs control.

2. design and apply risk management in a manner as to avoid arbitrary or unjustifiable discrimination, or disguised restrictions on international trade.

3. concentrate customs control and, to the extent possible other relevant border controls, on high risk consignments and expedite the release of low risk consignments. It may also select, on a random basis, consignments for such controls as part of its risk management.

4. base risk management on assessment of risk through appropriate selectivity criteria. Such selectivity criteria may include, inter alia, HS code, nature and description of the goods, country of origin, country from which the goods were shipped, value of the goods, compliance record of traders, and type of means of transport (WTO, 2013, pp. 8-9).

In the European Union the using of customs risk management is established in the Union Customs Code and EU Customs Blueprints. Therefore much attention is paid to customs risk management in the Association Agreement between the European Union and its Member States, and Ukraine (2014). Provisions of Association Agreement chapter 5 'Customs and trade facilitation' set that EU and Ukraine respective trade and customs legislation shall be stable and comprehensive. Besides provisions and procedures shall be proportionate, transparent, predictable, non-discriminatory, impartial and applied uniformly and effectively and shall inter alia: apply modern customs techniques, including risk assessment, post clearance controls and company audit methods in order to simplify and facilitate the entry and release of goods.

The Ukraine also has own experience of using risk management principles into its customs control formalities since 2005 .

The implementation of the customs risk management system in Ukraine took four stages (Razumiej \& Razumiej, 2017, 2018): the initial (preparatory) stage (1999-2005), the stage 
of formation (2005-2009), the stage of improvement (2009-2012) and the stage of integrated development (commenced with 2012). Each stage is characterized by certain achievements in the fields of legislative, organizational and information provision.

The key point in introducing the customs risk management methodology in Ukraine was approved Concept of the creation, implementation and development of a system for analysis and risk management in 2005. According to the Concept, the customs authorities of Ukraine during customs control should be guided by the principle of selectivity and, as a rule, be limited to the forms of customs control that are sufficient to ensure compliance with the customs legislation of Ukraine.

In 2005 the the Department of Risk Analysis and Audit was established in the structure of the State Customs Service of Ukraine. In 2006 the creation of an automated risk analysis and management system (hereinafter-ARAMS) began.

Further the risk management system was developed and improved, integrating into the system of general management of the customs authorities.

ARAMS provides automated data comparison within particular transactions, matching them with programmed algorithms (that is, risk profiles). Where potential risks of a breach of customs law are identified, the customs inspector is automatically given the list of customs formalities (forms of customs control) which must be applied in order to further assess the identified risks (Komarov, 2016, p.40).

To adjust the risk evaluation there is an opportunity to take into account the previous positive or negative operation history of foreign economic activity participants. Thus, it is possible to reduce the probability of ineffective ARAMS operations for a particular legal entity, carrier, and so on.

Komarov (2016, p. 39) recognizes, that it is not appropriate to rely solely and exclusively on the application of an automated system of risk management. Such a system is only one of the instruments for risk analysis and evaluation which helps to check relevant electronic documentation. At the same time, the importance of such automated systems should not be underestimated. Thus, we define the risk management system as a set of instruments of automated, manual and combined customs controls, based on the principle of selectivity within the scope of customs control required to ensure compliance with customs law.

At the legislative level the use of risk management systems during the selection of customs control forms was defined in 2012 in chapter 52 'Risk Management System' of the current Customs Code of Ukraine. So, the 2012 edition of the Customs Code of Ukraine is designed in accordance with the Kyoto and Istanbul Conventions, the International Convention on the Harmonization of Frontier Controls of Goods and the Customs Code of the EU as well as the WCO Framework of Standards to Secure and Facilitate Global Trade. It provides for flexibility and tailored solutions to enable relevant risk management and administrative strategies to be implemented.

The biggest problem was the inability to effectively manage risks at the central level, therefore, since 2012, the regional risk management and risk analysis at the border checkpoints began to develop. Considerable attention is also paid to the timely updating of the risk profiles to maintain a balance between regulatory control and trade facilitation.

In order to comply with the provisions of the Customs Code, in 2015 the Order of risk analysis and assessment, development and implementation of risk management measures for determination of forms and scope of customs control was adopted by Ministry of Finance of Ukraine. This Order is developed for the purpose of ensuring selectivity of customs control by application of risk management system with use of information technologies and defines the 
peculiarities of application the ARAMS, which has been integrated into the Ukrainian customs database 'Inspector'. Also this Order differentiated the concepts of fiscal risks and not fiscal (security) risks.

To speed up customs formalities at the state border of Ukraine, when analyzing and assessing risks, preference is given to the approach whereby non-fiscal risks, as well as risks of non-delivery of goods to customs of destination or their replacement are mainly analyzed and assessed at the checkpoints across the customs border there. In the customs of destination during the customs control and clearance of goods, fiscal and non-fiscal risks are checked. Fiscal risks are meant risks, the identification of which are aimed at preventing the minimization of the payment of taxes and fees, customs and other payments in the implementation of foreign economic operations. Non-fiscal (security) risks are the risks, the identification of which are aimed at ensuring the protection of national security, life and health of people, animals, plants, the environment, and the interests of consumers.

The Ukrainian customs administration applies such instruments of risk management as risk indicators and profiles, orientation, random selection and methodical recommendations.

Creating a software module 'The risk profile designer' in 2015 allows the customs officers in regional customs to fill their risk profiles independently with the indicators relevant to the regional threats. In addition, after the launch of the Single Window system in 2016, it was possible to integrate the information systems of different controlling authorities, allowing the creation of interagency risk profiles.

In 2017 the Cabinet of Ministers of Ukraine adopted the development the Strategy for the Development of a Risk Management System in the Field of Customs Control for the Period up to 2022 and the action plan for its implementation. According to it the Department of Targeting and Customs Risk Management was created in 2017 to enhance coordination and increase the effectiveness of the risk management system in the regions.

Nowadays the perspective of development Ukrainian ARAMS is the implementing the National Customs Enforcement Network (hereinafter - nCEN) of WCO and the European transit system, the New Computerised Transit System (hereinafter - NCTS) to enhance the effectiveness of national customs risk management.

The nCEN software will enable the SFS to efficiently collect, store, analyze and disseminate law enforcement intelligence at the national level in order to enhance the operational capabilities of the SFS Customs, as well as to improve risk profiling at the strategic, tactical and operational levels. This includes schematising the risks and groups of goods, routes and trading companies that are potentially exposed to the violation of customs rules.

The use of nCEN will facilitate a more active exchange of information between customs authorities at the regional and international levels, enhance cooperation between all sectors of the border.

The nCEN consists of three independent databases. The principal database of national seizures and offences comprises data required for analysis, as well as means of conveyance, routes, and the possibility to view photos depicting exceptional concealment methods. Two supplementary databases contain information on suspect persons, methods of conveyance and business entities of interest to Customs, thereby facilitating a structured investigation process

Since 2009, in the territory of the European Community, all transit operations under the TIR Convention was necessarily carried out using the European Customs Information System NCTS which will process the declaration and control the transit movement. 
In our opinion, integrated risk management as an integral part of the customs authorities activity will allow not only to effectively implement the initiated state reforms, but also to create a sound basis for the development of the customs system as a modern innovation-oriented institution.

Therefore, the introduction of integrated risk management in the activities of the Ukrainian customs authorities, should begin, first of all, with the formation of a risk-taking culture, which should increase the managerial competence of customs officials. The main element of the risk management culture is to bring the general attitude to risk and related organizational values and priorities to the attention of the employees involved in the decision-making process at all levels of management. Equally important, the goal is to maintain a sufficient level of competence for managers of all key areas of risk assessment and management.

According to Risk Management Compendium (WCO, 2011) the maturity model of risk management is assessed in relation to the main characteristics (culture, process, infrastructure) and based on five different levels of risk management maturity: naive, conscious, defined, managed, included.

Establishing a risk maturity model is important as it allows a common baseline to be established against which risk management practices could be benchmarked. Administrations should define and design a model that fits their unique context.

We can assess the maturity of risk management in the customs authorities of Ukraine at the level of 'risk defined', because the application of this methodology is already some extent standardized with the high-level management of the policy, processes and degree of risk acceptance. However, despite the transition to the stage of integrated development of the risk management system, officials of the customs authorities of Ukraine will have to make significant efforts in implementing the necessary changes aimed at introducing an integrated risk- management, which will cover all areas of their business activities and should become the basis of the customs authorities management.

Besides, implementing of integrated risk-management according to the standard ISO 31000 should be done on the basis proposed innovative model with such technologies as:

1. Change management. Changes are related to both external and internal conditions of customs and border control, especially trends and methods of violations of legislation in this field.

2. Knowledge management. The rapid growth of information is as a risk and as an ability for customs administrations. The risk is related to the increased complexity of information management in the context of its effective collection and conversion into the accessible form for quality decision-making.

3. Quality management. The quality customs services for business community and citizens, providing quality control of compliance with law with cross-borders, needs an adherence to standards of quality control to ensure both internal support of the customs and border authorities and realization of processes at the border by them.

It should be noted that the use of these technologies should be periodically benchmarked. Benchmarking plays a significant role in the implementation of quality management and risk management systems, provides an opportunity to determine their own advantages and weaknesses, find directions for change and ways of innovation development. In the customs authorities it will be useful to apply the following types of benchmarking:

- international - borrowing of successful foreign experience and best achievements of customs administrations of the world; 


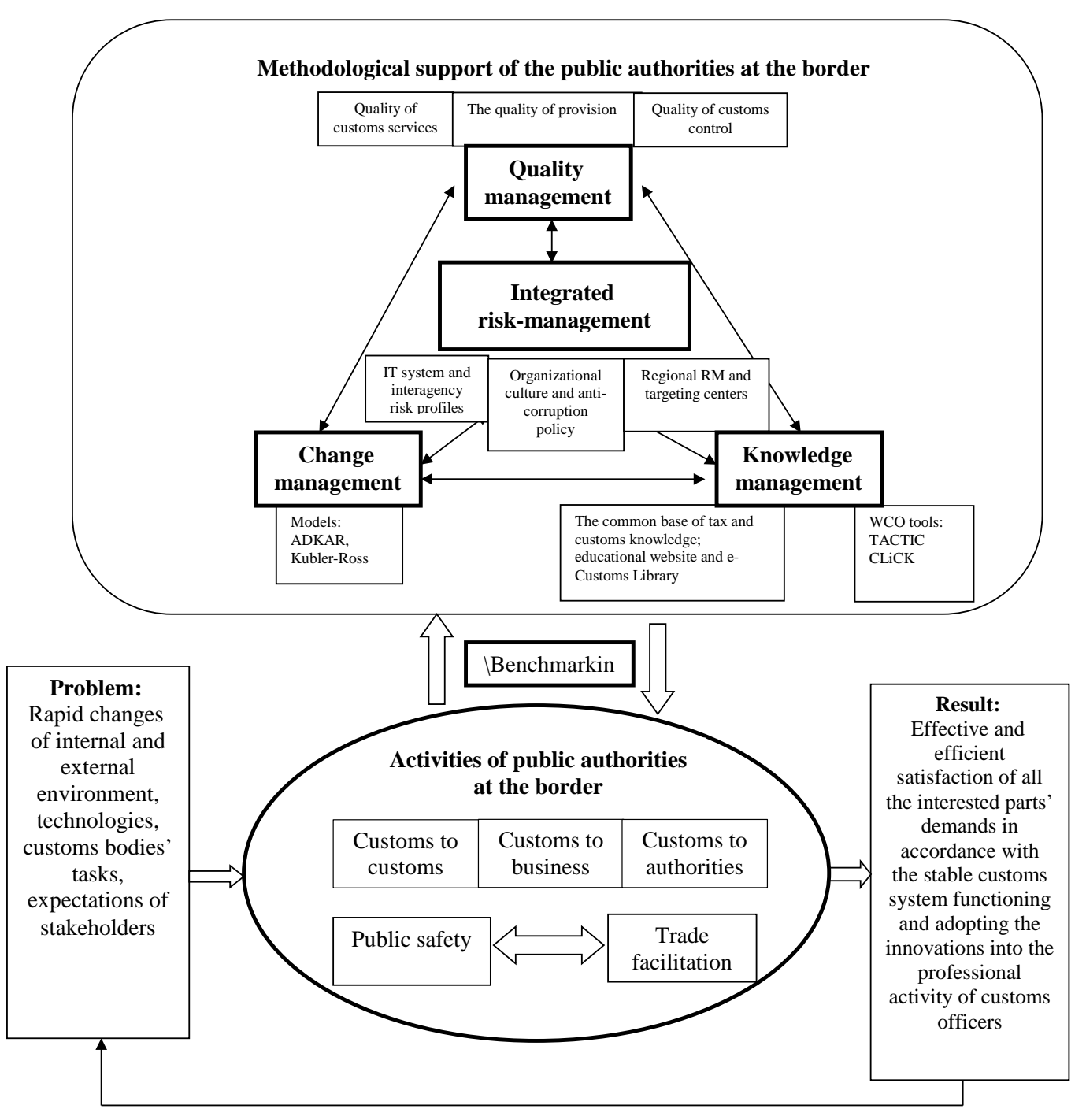

Fig. 1. The innovative model of integrated customs risk management

Source: compiled by the authors

- regional - studying the best practices in customs management in Ukraine, taking into account the specifics of foreign economic activity in the regions - the zones of activity of separate customs authorities;

- process or substantive - analysis and consideration of the best achievements in the implementation of customs formalities and innovations in management processes.

By using different types of benchmarking in relation to an object, subject or method of comparison, customs officials receive an instrument that allows formalizing the transfer and adaptation of advanced managerial experience. In addition, benchmarking is at the same time 
an educational tool for an organization that provides a continuous process of research and education, and also provides continuous and steady performance enhancements.

\section{Conclusion}

Besides, the implementing of integrated risk management according to the standard ISO 31000 should be done with the technologies of change, knowledge and quality management based on wider using of the European and national IT platform and interagency cooperation for development of regional risk management and establishing of interagency risk profiles. The proposed model will help to solve the permanent problem - rapid changes of internal and external environment, technologies, customs bodies' tasks, expectations of stakeholders - and to achieve of an expected result - effective and efficient satisfaction of all the interested parts' demands in accordance with the stable customs system functioning and adopting the innovations into the professional activity of customs officers.

Taking into account the international experience and domestic practice of applying customs risk management, we propose the following steps that will promote the implementation of integrated risk management in the customs authorities of Ukraine:

1) introduction of risk management in the organizational culture of customs authorities and bringing it to the level of strategic planning;

2) dissemination of risk management awareness among officials of the customs authorities of Ukraine and support of senior management of the process of its implementation;

3 ) construction of the risk register for the customs system in general and each customs authority separately;

4) determination of respondents for each individual type of risk and their promotion system, formation of risk managers competencies in managers of different levels of management;

5) integration of risk management with the quality management system of the customs authorities of Ukraine in order to effectively achieve its main objectives;

6) introduction of annual reporting on the effectiveness of risk management and review of the risk register of customs authorities in Ukraine.

\section{References:}

1. Association Agreement between the European Union and its Member States, of the one part, and Ukraine, of the other part (2014). Retrieved from https://eeas.europa.eu/sites/eeas/files/ association_agreement_ukraine_2014_en.pdf.

2. Berezhnyuk, $\bar{I} . H$. (2009). Mytne rehulyuvannya Ukrayiny: natsionalni ta mizhnarodni aspekty [Customs regulation of Ukraine: national and international aspects]. Dnipropetrovsk: Academy of Customs Service of Ukraine [in Ukrainian].

3. Berezhnyuk, I.H. (Eds). (2014). Upravlinnya ryzykamy v mytniy spravi: zarubizhnyy dosvid ta vitchyznyana praktyka [Risk management in customs affairs: foreign experience and domestic practice]. Khmelnytsky: PP Melnik A.A. [in Ukrainian].

4. Borisenko, O.P. (2012). Zovnishnoekonomichna polityka derzhavy: kontseptsiya, stratehiya, mekhanizmy realizatsiyi [Foreign economic policy of the state: concept, strategy, mechanisms of realization]. Donetsk: Yuho-Vostok [in Ukrainian].

5. Cabinet of Ministers of Ukraine (2017). Order from 27 December, 2017, No. 978. On approval of the Strategy for the Development of a Customs Risk Management System in the Field of Customs Control for the Period up to 2022.

6. Chentsov, V.V. (2012). Mekhanizmy derzhavnoho upravlinnya mytnoyu spravoyu [Mechanisms of state administration of customs affairs]. Dnipropetrovsk: Academy of Customs Service of Ukraine [in Ukrainian]. 
7. Czyżowicz, W. (2015). Polityczno-prawne i organizacyjne formy zwalczania przestępstw celnych w ramach WCO [Politico-legal and organizational forms of combating customs offenses under the WCO]. Monitor Prawa Celnego i Podatkowego, 2/235, 52-60. [in Polish].

8. Customs Code of Ukraine (2012). Kyiv: Verkhovna Rada of Ukraine.

9. International Organization for Standardization (2018). International standart ISO 31000:2018 'Risk management - Guidelines'. Retrieved from https://www.iso.org/iso-31000-riskmanagement.html.

10. Ivashova (Pismachenko), L.M. (2008). Derzhavne upravlinnya zovnishnotorhovelnoyu diyal'nistyu v Ukrayini: rehulyuvannya ta kontrol [State administration of foreign trade activity in Ukraine: regulation and control]. Donetsk: Yuho-Vostok [in Ukrainian].

11. Jeacocke, S., \& Kouwenhoven N. (2017). Cognitive computing for Customs agencies: improving compliance and facilitation by enabling Customs officers to make better decisions. WCO News, 82, 28-30. Retrieved from https://mag.wcoomd.org/uploads/2018/05/WCO news 82.pdf.

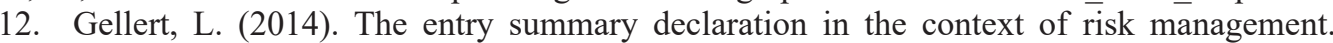
Customs Scientific Journal CUSTOMS, 4(2), 27-34. Retrieved from https://www.ccjournals.eu/ojs/ index.php/customs/article/view/505.

13. Komarov, O. (2016) Risk management systems in Customs: the Ukrainian context. World customs journal, V.10, N. 1, 35-44. Retrieved from http://worldcustomsjournal.org/archive/volume10-number-1-march-2016/

14. Kveliashvili, I. M. (2010). Rozvytok Derzhavnoyi mytnoyi sluzhby Ukrayiny yak subyekta natsionalnoyi bezpeky Ukrayiny [Development of the State Customs Service of Ukraine as a Subject of National Security of Ukraine]. Candidate's thesis. Dnipropetrovsk: Dnipropetrovs'k regional institute of public administration. (in Ukrainian)

15. Mashiri, E., \& Sebele-Mpofu, F. (2016). Illicit trade, economic growth and the role of Customs: a literature review. World Customs Journal, 9 (2), 38-50.

16. Mikuriya, K. (2017). 'International Customs Day 2017. Data Analysis for Effective Border Management'. Retrieved from http://www.wcoomd.org/en/about-us/international-customs-day/ previous-editions/icd-2017.aspx.

17. Ministry of Finance of Ukraine (2015). Decree from 31 July, 2015, No. 684. On approval of the Order of risk analysis and assessment, development and implementation of risk management measures for determination of forms and scope of customs control.

18. Official Website of the State Fiscal Service of Ukraine. Retrieved from http://sfs.gov.ua.

19. Pashko P. V. (2009) Mytna bezpeka (teorija, metodologhija ta praktychni rekomendaciji) [Customs security (theory, methodology and practical recommendations)]. Odesa: Plaske. (in Ukrainian)

20. Razumiej, G., \& Razumiej M. (2017) Tendencje rozwoju zarządzania ryzykiem w celnictwie ukraińskim. Monitor Prawa Celnego i Podatkowego, 3 (260), 101-106. Retrieved from http://monitorc.pl/art/3538/ tendencje rozwoju zarzadzania ryzykiem w celnictwie ukrainskim .

21. Razumiej, G., \& Razumiej M. (2018) Struktura Państwowej Służby Skarbowejej Ukrainy w kontekście zarządzania ryzykiem celnym. Monitor Prawa Celnego i Podatkowego. Retrieved from: https://monitorc.pl/art/3701/_struktura_panstwowej_sluzby_skarbowej_ukrainy_w_kontekscie_ zarzadzania_ryzykiem_celnym.

22. Risk management: an upgraded version of the nCEN now available (2016). WCO News, 80, 14-15. Retrieved from https://mag.wcoomd.org/uploads/2018/08/wco_news_80.pdf.

23. State Customs Service of Ukraine (2005). Decree from 27 May, 2005, No. 435. On approval of the Concept of the creation, implementation and development of a system for analysis and risk management.

24. Tereschenko, S.S. (2012). Osnovy ryzyk-menedzhmentu v mytniy spravi ta zovnishnoekonomichniy diyalnosti [Fundamentals of risk management in customs and foreign economic activity]. Odesa: Plaske [in Ukrainian].

25. Using the New Computerised Transit System (NCTS) to move goods (2018). Retrieved from https://www.gov.uk/guidance/using-the-new-computerised-transit-system-to-move-goodsacross-the-eu-and-efta-countries. 
26. Widdowson, D. (2003). Intervention by Exception: A Study of the use of Risk Management by Customs Authorities in the International Trading Environment: A thesis submitted in fulfilment of the requirements for the degree of Doctor of Philosophy. University of Canberra. Retrieved from: http://customscentre.canberra.edu.au/storage/ Intervention by Exception.pdf

27. WCO (1999). International Convention on the Simplification and Harmonization of Customs Procedures (as amended). Retrieved from http://www.wcoomd.org/Topics/Facilitation/ InstrumentandTools/Conventions/pf revised kyoto conv/Kyoto_New.

28. WCO (2003). Risk management guide. Brussels: WCO. Retrieved from: www.adb.org/ documents/events/2005/trade-facilitation/wco-risk-guide- eng.pdf.

29. WCO (2007, update 2018). SAFE Framework of Standards to Secure and Facilitate Global Trade. Brussels: WCO. Retrieved from: http://www.wcoomd.org/en/topics/facilitation/instrumentand-tools/frameworks-of-standards/safe package.aspx.

30. WCO (2008). Customs in the 21 st century. Enhancing Growth and Development through Trade Facilitation and Border Security. Retrieved from http://www.wcoomd.org/files/1.Publicfiles/ PDFandDocuments /AnnexII-Customs in the 21st Century.pdf.

31. WCO (2011). Risk Management Compendium. Retrieved from http://www.wcoomd.org/ en/topics/enforcement-and-compliance/instruments-and-tools/compendiums/rmc.aspx.

32. WCO (2016-2019). International Customs Day. Retrieved from http://www.wcoomd.org/ en/about-us/international-customs-day.aspx.

33. WTO (2013). Trade Facilitation Agreement. Retrieved from https://www.wto.org/english/ thewto_e/minist_e/mc9_e/desci36_e.htm.

\title{
УПРОВАДЖЕННЯ ІНТЕГРОВАНОЇ СИСТЕМИ УПРАВЛІННЯ МИТНИМИ РИЗИКАМИ
}

\author{
Галина РАЗУМЕЙ, \\ дочент кафедри публічного управління та митного адміністрування \\ Університету митної справи та фінансів \\ кандидат наук з державного управління \\ galchata86@gmail.com \\ Максим РАЗУМЕЙ, \\ Начальник відділу з управління ризиками \\ Дніпропетровської митниці ДФС, \\ кандидат наук з державного управління \\ m.razumey@gmail.com
}

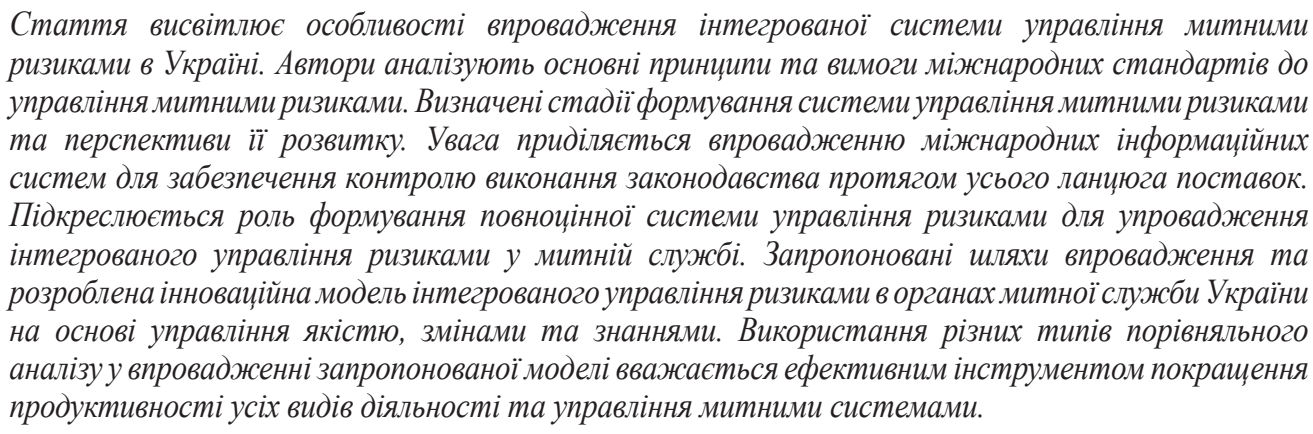

Ключові слова: міжнародні стандарти, інтегроване управління ризиками, митні ризики система автоматичного аналізу та управління ризиками, інноваційна модель, управління якістю, управління змінами, управління знаннями. 